\title{
Aplikasi Zeolit Alam Aktif Wonosari Sebagai Adsorben Zat Warna Remazol Yellow Fg
}

\author{
Active Natural Zeolit Application in Wonosari \\ as Adsorbent of Remazol Yellow Fg Color Substance
}

\author{
Neni Damajanti ${ }^{*}$, Anwar Ma'ruf ${ }^{2}$, Hanafi Khafid Nugraha ${ }^{3}$ \\ 1,2,3Program Studi Teknik Kimia, Fakultas Teknik dan Sains, Universitas Muhammadiyah Purwokerto
}

\begin{tabular}{l}
\hline \hline ARTICLE INFO \\
\hline Article history: \\
DOI: \\
10.30595/pspfs.v1i.138 \\
Submitted: \\
June 27, 2021 \\
Accepted: \\
July 12, 2021 \\
Published: \\
Oct 31, 2021 \\
\hline
\end{tabular}

Keywords:

Adsorption, Isotherm, Remazol Yellow FG, Active Zeolite

\begin{abstract}
Zeolite as an adsorbent has been widely used. Zeolite activation was carried out to increase the absorption. This study aimed to determine the characteristics of the active zeolite and apply it as an adsorbent. The activation process was carried out by adding acid and calcining at 4500C for 6 hours. Remazol Yellow FG is a dye that is widely used in the textile industry. In this study, the adsorption process was carried out on the Remazol Yellow FG solution, then analyzed the effect of changes in $\mathrm{pH}$ $(5,6,7,8,9)$, contact time $(30,60,90,120,150$ minutes $)$ and the concentration of Remazol Yellow FG solution ( 50, 100, 150, 200, $250 \mathrm{ppm}$ ) on the adsorption of Remazol Yellow FG dye. From the analysis of the sample solution of Remazol Yellow, the values of $\mathrm{Ce}$ and qe can be calculated. These values were then used to calculate $\mathrm{KL}$ and $\mathrm{KF}$ in the Langmuir adsorption isotherm and Freundlich adsorption isotherm models. From the experimental results, it could be seen that as the contact time increased, the adsorption capacity would be greater. However, when the zeolite was already in the saturated phase, the adsorption capacity would tend to decrease. In the Langmuir adsorption isotherm, the $\mathrm{KL}$ value was $0.0274 \mathrm{~L} / \mathrm{mg}$ and in the Freundlich adsorption isotherm model, the KF value was $29.25 \mathrm{~L} / \mathrm{mg}$. Remazol Yellow FG adsorption tended to follow the Langmuir adsorption isotherm model with an R2 value of 0.998 .
\end{abstract}

This work is licensed under a Creative Commons Attribution 4.0 International License.

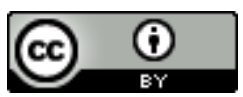

\section{Corresponding Author:}

Neni Damajanti

Program Studi Teknik Kimia, Fakultas Teknik dan Sains, Universitas Muhammadiyah Purwokerto

J1. KH. Ahmad Dahlan, PO BOX 202 Purwokerto 53182

Email: damajantineni9@gmail.com

\section{PENDAHULUAN}

Berkembang pesatnya ilmu pengetahuan dan teknologi di Indonesia, juga diiringi dengan meningkatnya berbagai aktivitas industri. Industri tekstil merupakan salah satu sektor industri yang telah mengalami peningkatan secara signifikan tiap tahunnya. Selain memberikan dampak positif, peningkatan aktivitas industri juga diiringi dengan timbulnya berbagai permasalahan lingkungan. Aktivitas industri tekstil akan menghasilkan berbagai macam bentuk limbah, salah satunya adalah limbah zat cair (Gao et al., 2013). Umumnya, sistem pengeloloaan yang kurang memadai dan tingginya biaya pengelolaan limbah mengakibatkan unit-unit industri membuang limbahnya secara langsung ke dalam sungai (Zhong et al., 2014). Hal tersebut tentunya akan berdampak langsung terhadap penurunan kualitas air sungai.

Umumnya, limbah cair industri tekstil mengandung zat-zat berbahaya, salah satunya adalah zat warna. Berbagai jenis zat warna sintetik yang digunakan secara komersil pada industri tekstil diantaranya adalah, methylene blue, remazol brilliant dan remazoll yellow. Setidaknya 10-15\% dari zat warna yang digunakan tidak akan terserap ke dalam 
serat pakaian, sehingga harus dibuang ke tempat penampungan limbah. Zat-zat warna tersebut bersifat tidak ramah lingkungan karena sukar diuraikan dan relatif beracun jika dikonsumsi oleh manusia (Dehghani et al., 2017; Ngah et al., 2011; Wang dan Peng, 2010). Remazol Yellow FG merupakan salah satu jenis zat warna sintetik komersil dalam industri tekstil. Sekitar 27,2 \% industri tekstil telah menggunakan Remazoll Yellow FG sebagai zat warna. Secara kimia, struktur zat warna Remazoll Yellow FG tediri dari senyawa azo (-N=N-) yang memiliki kestabilan kimia yang tinggi sehingga bersifat sukar diuraikan secara langsung oleh alam (Aydin, 2011 dan Handayani et al., 2016). Beberapa upaya yang telah dilakukan untuk menangani permasalahan pencemaran zat warna dalam larutan diantaranya adalah degradasi fotokatalitik, elektrokimia, koagulasi, fisikokimia, pertukaran ion dan adsorpsi (Handayani et al., 2016 dan Wahyuningsih et al., 2017). Berdasarkan metode-metode tersebut, metode adsorpsi merupakan metode yang relatif bagus dan cocok untuk menghilangkan berbagai macam zat warna (Humelnicu et al., 2016 dan Ngah et al., 2011). Metode adsorpsi memiliki keunggulan dibandingkan dengan metode lain, diantaranya adalah memiliki daya operasional yang mudah, murah, efektif, dapat menghilangkan bau dan dapat digunakan pada konsentrasi zat warna yang rendah tanpa mengubahnya menjadi zat yang lebih berbahaya (Dehghani et al., 2017; Handayani et al., 2016 dan Saputra et al., 2017).

Salah satu material yang sering digunakan sebagai adsorben zat warna adalah dengan menggunakan material zeolit. Zeolit merupakan material berpori yang tersusun oleh mineral alumina silika dan keberadaannya telah diteliti secara luas untuk berbagai bidang, salah satunya adalah sebagai adsorben (Ngah et al., 2011). Berbagai jenis zeolit sintetik telah dikembangkan secara masif sebagai adsorben efektif (Liu et al., 2014; Li et al., 2015 dan Yan et al., 2016). Akan tetapi, zeolit sintetik masih memiliki harga yang relatif mahal sehingga perlu dilakukan pencarian material alternative, seperti zeolit alam (ZA). Keberadaan ZA di Indonesia tergolong melimpah. Menurut Sriningsih et al (2014) sebanyak 205,82 juta ton ZA terdistribusi dibeberapa wilayah Indonesia, salah satunya di daerah Wonosari, Yogyakarta.

Menurut Khairinal, Trisunaryanti (2000), ZA Wonosari memiliki kandungan utama berupa mordenit sebesar $70 \%$ dengan kadar silika yang tinggi sehingga banyak diminati oleh peneliti-peneliti sebelumnya sebagai katalis dalam berbagai jenis reaksi. Penggunaan ZA sebagai adsorben secara langsung masih memiliki kelemahan diantaranya adalah rendahnya kapasitas adsorpsi terhadap adsorbat. Hal tersebut disebabkan oleh tingginya kadar pengotor yang menutupi situs aktif di dalam zeolit (Montalvo et al., 2012). Oleh karena itu, perlakuan awal berupa aktivasi baik secara fisika maupun kimia perlu dilakukan guna meningkatkan kualitas ZA untuk digunakan sebagai adsorben efektif terhadap zat warna Remazoll Yellow FG (Mockovčiaková et al., 2008). Berdasarkan uraian tersebut, maka dipandang perlu dilakukan aktivasi zeolit alam menjadi zeolit alam aktif (ZAA). Aktivasi zeolit alam diharapkan dapat digunakan sebagai material adsorben yang efektif dalam menyerap zat warna tekstil Remazol Yellow, sehingga pencemaran lingkungan dapat dikurangi.

\section{METODE PENELITIAN}

\section{Aktivasi Zeolit}

Zeolit diaktivasi berdasarkan penelitian Saputra (2018), sebanyak 10 g zeolit alam direndam dengan HF $1 \%$ untuk melarutkan oksida-oksida pengotor yang terdapat pada luar kerangka zeolit. Padatan zeolit disaring dan dicampur dengan $100 \mathrm{~mL} \mathrm{HCl} 6 \mathrm{~N}$ sambil dipanaskan selama 30 menit pada temperatur $50{ }^{\circ} \mathrm{C}$. Campuran kemudian disaring dan dicuci hingga netral dengan menggunakan akuades. Uji bebas $\mathrm{Cl}^{-}$dilakukan menggunakan larutan $\mathrm{AgNO}_{3}$. Zeolit selanjutnya dioven pada temperatur $130{ }^{\circ} \mathrm{C}$ selama 3 jam. Kemudian, zeolit dicampur dengan $100 \mathrm{~mL}$ $\mathrm{NH}_{4} \mathrm{Cl}$ selama 7 hari dan dipanaskan pada temperatur $90{ }^{\circ} \mathrm{C}$. Setelah selesai, campuran disaring, dinetralkan dengan akuades dan diuji bebas $\mathrm{Cl}^{-}$dengan larutan $\mathrm{AgNO}_{3}$. Padatan zeolit kemudian dioven pada suhu $130{ }^{\circ} \mathrm{C}$ selama 3 jam untuk menghasilkan zeolit alam- $\mathrm{NH}_{4}{ }^{+}\left(\mathrm{ZA}-\mathrm{NH}_{4}^{+}\right)$. Kemudian $\mathrm{ZA}-\mathrm{NH}_{4}{ }^{+}$dikalsinasi pada suhu $450{ }^{\circ} \mathrm{C}$ selama 6 jam untuk membentuk ZAA.

\section{Pengaruh Perubahan pH}

Sebanyak 0,2 gram zeolit dan $20 \mathrm{~mL}$ larutan Remazol Yellow FG 50 ppm yang telah diatur pH-nya mulai dari 5, 6, 7, 8 dan 9 dimasukkan ke dalam labu erlenmeyer $100 \mathrm{~mL}$. Pengaturan $\mathrm{pH}$ larutan dilakukan dengan menambahkan $\mathrm{HCl} 0,1 \mathrm{M}$ atau $\mathrm{NaOH}$ 0,1 M. Labu erlenmeyer tersebut diaduk menggunakan magnetic stirrer kecepatan skala 4 selama 120 menit, kemudian hasilnya dilakukan sentrifugasi pada kecepatan 5000 rpm selama 10 menit, dan diukur absorbansinya pada panjang gelombang $413 \mathrm{~nm}$ dengan menggunakan spektrofotometer UV-Vis.

\section{Pengaruh Perubahan Waktu Kontak}

Sebanyak 0,2 gram zeolit dan $20 \mathrm{~mL}$ larutan Remazol Yellow FG konsentrasi 50 ppm dimasukkan ke dalam labu erlenmeyer dengan $\mathrm{pH}$ optimum yang diperoleh. Labu erlenmeyer tersebut diaduk menggunakan magnetic stirrer 
kecepatan skala 4 dengan variasi waktu 30, 60, 90, 120, dan 150 menit. Larutan dilakukan sentrifugasi pada kecepatan $5000 \mathrm{rpm}$ selama 10 menit dan dianalisis konsentrasinya dengan spektrofotometer UV-Vis.

\section{Penentuan Kapasitas Adsorpsi}

Besarnya kapasitas adsorpsi dihitung berdasarkan persaaam isoterm adsorpsi Langmuir dan Freunlich. Dari perhitungan didapatkan nilai koeefisien determinasi dimana akan memberikan gambaran mekanisme reaksi yang tejadi selama adsorpsi.

\section{HASIL DAN PEMBAHASAN}

\section{Karakterisasi Zeolit dengan XRD}

ZA dikarakterisasi dengan spektrofotometer XRD dengan maksud untuk mengetahui jenis fase dari material awal ZA dan setelah aktivasi (ZAA). Hasil karakterisasi kemudian dibandingkan dengan standar fase mordenit (JCPDS 80-0645) dan ditunjukkan pada Gambar 1. Berdasarkan hasil analisa, data difraktogram ZA memiliki tingkat kemiripan dengan puncak-puncak dari standar mordenit. Hal tersebut ditandai dengan munculnya puncak-puncak intensitas yang tajam di daerah $2 \theta$ yang merupakan karakteristik dari mordenit $(2 \theta=9,62 ; 13,34 ; 19,52 ; 22,14 ; 23,15$; 25,57; 26,39; 27,49, 30,92 dan 35,6 $)$. Munculnya puncak-puncak lain selain puncak-puncak karakteristik mordenit merupakan puncak-puncak dari fase klinoptilotit. Proses aktivasi baik secara fisik dan kimia pada ZA menyebabkan penurunan intensitas puncak di daerah $2 \theta=20,70^{\circ} ; 22,46^{\circ} ; 25,81^{\circ}$ dan $29,85^{\circ}$. Penurunan intensitas puncak pada $2 \theta$ tersebut mengindikasikan adanya kerusakan terhadap struktur kristal klinoptilotit. Selain itu, sisi amorf ZA telah mengalami penurunan yang diindikasikan dengan adanya penurunan intensitas pada puncak yang melebar di daerah $2 \theta=5,4^{\circ}$ (Saputra et al., 2017).

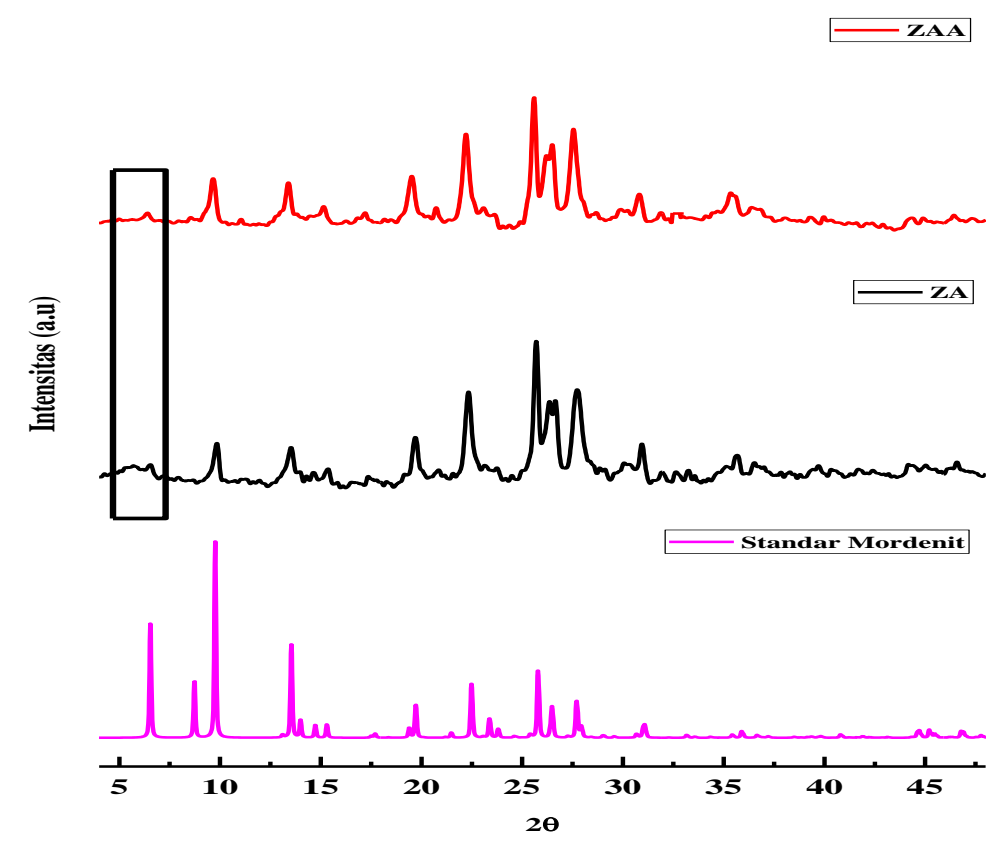

Gambar 1. Difraktogram ZA dan ZAA dibandingkan dengan (JCPDS 80-0645) mordenit

\section{Karakterisasi Zeolit dengan FTIR}

Karakterisasi dengan FTIR memberikan informasi mengenai karakteristik gugus fungsi dari masing-masing material baik ZA dan ZAA. Adapun spektra infra merah dari ZA dan ZAA disajikan pada Gambar 2. Serapan-serapan utama dari ZA terdiri dari serapan -OH ulur dan tekuk yang secara berturut-turut muncul pada daerah $3462 \mathrm{~cm}^{-1}$ dan $1650-1600 \mathrm{~cm}^{-1}$. Adanya proses aktivasi secara asam dapat menurunkan kadar air yang terkandung di dalam kerangka zeolit yang diindikasikan dengan adanya penurunan serapan vibrasi ulur dari gugus O-H dari molekul air di daerah $3462 \mathrm{~cm}^{-1}$ pada ZAA. Menurut Saputra et al (2017) dan Prasetyo (2018) adanya penurunan kadar air merupakan indikasi bahwa pori-pori ZA mengalami pelebaran dan telah bersih dari pengotor. 


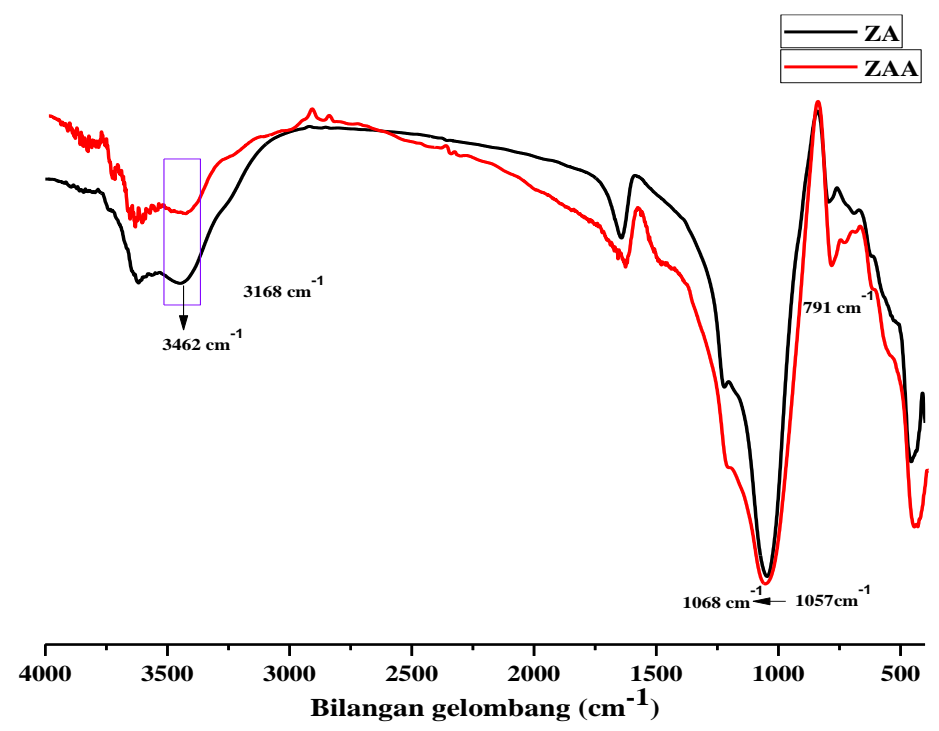

Gambar 2. Spektra infra merah dari ZA (Zeolit alam), dan ZAA (zeolit alam aktif)

Proses aktivasi ZA dengan asam, menyebabkan pergeseran serapan di daerah $1057 \mathrm{~cm}^{-1}$ pada ZAA menuju bilangan gelombang yang lebih tinggi yaitu $1068 \mathrm{~cm}^{-1}$, hal ini mengindikasikan bahwa ZA telah mengalami proses dealuminasi. Dealuminasi yaitu lepasnya Al bebas dari kerangka zeolit (Saputra et al., 2017 dan Prasetyo, 2018). Secara umum proses aktivasi pada ZAA tidak mengganggu struktur utama dari zeolit. Akan tetapi proses aktivasi dapat menurunkan tingkat pengotor pada zeolit. Hal tersebut dapat dibuktikan dari analisa XRD dan FTIR.

\section{Pengaruh Perubahan pH terhadap Adsorpsi}

pH merupakan salah satu faktor yang berpengaruh terhadap peristiwa adsorpsi suatu zat warna.. Adapun data hasil kapasitas adsorpsi pada 5 kondisi pH yang berbeda tersebut disajikan pada Gambar 3. Berdasarkan Gambar 3, kondisi pH optimum dicapai pada saat $\mathrm{pH} 6$, hal tersebut diindikasikan dengan optimumnya nilai kapasitas adsorpsi jika dibandingkan dengan $\mathrm{pH}$ lainnya yaitu sebesar $1,65 \mathrm{mg} / \mathrm{g}$. Menurut Handayani et al (2016), pada kondisi $\mathrm{pH}$ yang tidak terlalu asam maka proton $\left(\mathrm{H}^{+}\right)$mampu menyebabkan peristiwa protonasi dari zat warna Remazol Yellow FG (D$\mathrm{SO}_{2} \mathrm{CH}_{2} \mathrm{CH}_{2} \mathrm{OSO}_{3}-\mathrm{Na}^{+}$menjadi bentuk vinil sulfon (D-SO $-\mathrm{CH}=\mathrm{CH}_{2}$ ) secara parsial. Kemudian bentuk vinil sulfon akan mudah berinteraksi dengan situs aktif pada ZAA. Gambar 3 menunjukkan pengaruh pH terhadap kapasitas adsorpsi ZAA pada zat warnna Remazol Yellow FG.

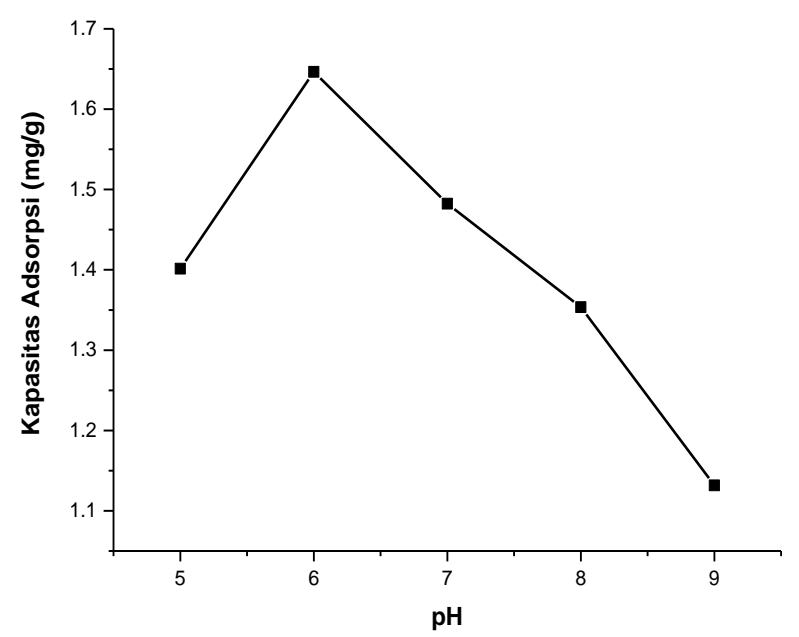

Gambar 3. Grafik pengaruh $\mathrm{pH}$ terhadap adsorpsi

Kondisi $\mathrm{pH}$ yang terlalu asam akan menyebabkan proton mampu memprotonasi semua D- $\mathrm{SO}_{2} \mathrm{CH}_{2} \mathrm{CH}_{2} \mathrm{OSO}_{3}-$ $\mathrm{Na}^{+}$menjadi bentuk vinil sulfon $\left(\mathrm{D}-\mathrm{SO}_{2}-\mathrm{CH}=\mathrm{CH}_{2}\right.$ ). Hal tersebut mengakibatkan adanya penurunan interaksi antara zat warna dengan ZAA. Sedangkan pada kondisi pH yang terlalu basa akan menyebabkan D- $\mathrm{SO}_{2} \mathrm{CH}_{2} \mathrm{CH}_{2} \mathrm{OSO}_{3}-\mathrm{Na}^{+}$ juga terkonversi sempurna menjadi bentuk vinil sulfon $\left(\mathrm{D}-\mathrm{SO}_{2}-\mathrm{CH}=\mathrm{CH}_{2}\right)$ akibat tingginya konsentrasi $\mathrm{OH}^{-}$. 
Terkonversinya gugus sulfonate menjadi sulfon akan menyebabkan penurunan kapasitas adsorpsi. Hal tersebut dikarenakan gugus sulfonat merupakan gugus reaktif yang mana dengan mudah terdisosiasi dan berubah menjadi bentuk ionnya sehingga dapat dengan mudah berinteraksi dengan situs aktif ZAA.

\section{Pengaruh Waktu Kontak terhadap Adsorpsi}

Penentuan waktu kontak optimum bertujuan untuk menetukan waktu yang dibutuhkan suatu ZAA untuk mengadsorpsi secara maksimal zat warna Remazol Yellow FG. Studi variasi waktu kontak dilakukan pada waktu 30, 60, 90, 120 dan 150 menit. Adapun pengaruh waktu kontak terhadap kapasitas adsorpsi ZAA pada zat warna Remazol Yellow FG disajikan pada Gambar 4. Berdasarkan data pada Gambar 4, waktu kontak optimum dicapai pada waktu kontak sebesar 120 menit. Hal tersebut diindikasikan dengan optimumnya nilai kapasitas adsorpsi ZAA terhadap zat warna Remazol Yellow FG yaitu sebesar $1,77 \mathrm{mg} / \mathrm{g}$. Hasil tersebut menunjukkan bahwa ZAA mengadsorpsi secara sempurna zat warna Remazol Yellow FG pada waktu 120 menit. Nilai kapasitas adsorpsi pada waktu kontak 150 menit mengalami penurunan yang disebabkan oleh kondisi jenuh dari adsorben ZAA sehingga tidak dapat melakukan adsorbsi secara optimal. Kondisi jenuh akan menyebabkan ZAA akan melepas kembali sebagian zat warna ke dalam sistem larutan sehingga menyebabkan penurunan nilai kapasitas adsorpsi.

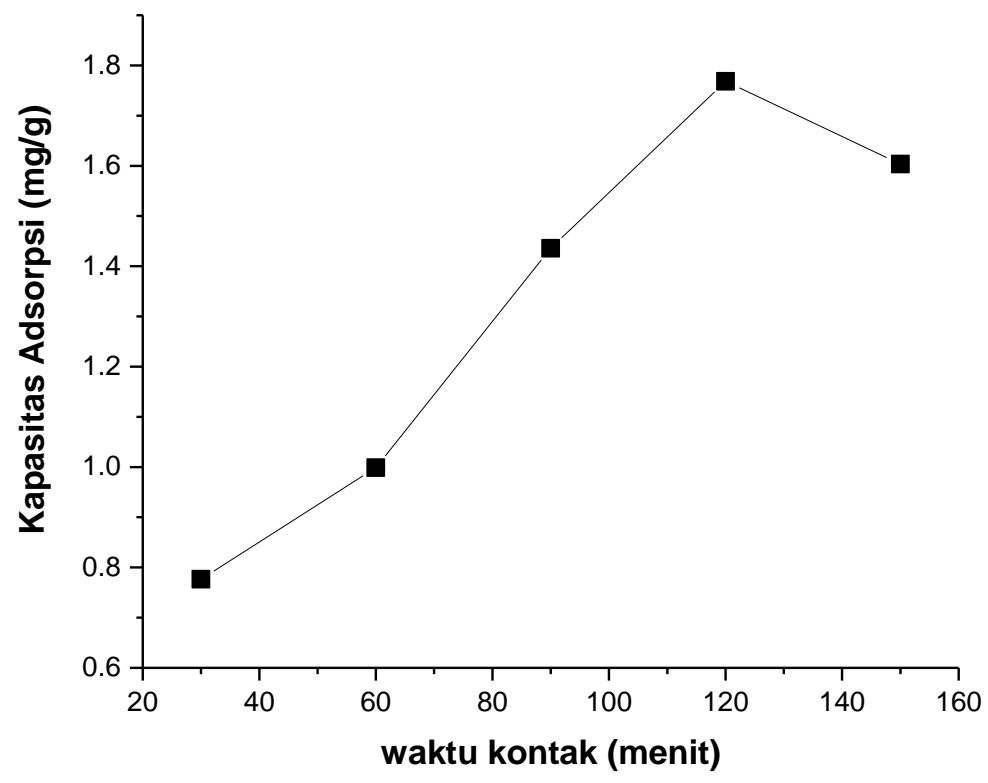

Gambar 4. Grafik pengaruh waktu kontak terhadap adsorpsi

\section{Penentuan Kapasitas Adsorpsi}

Analisa dilakukan dengan menggunakan metode isoterm Langmuir dan Freundlich. Penentuan isoterm ditentukan dengan menggunakan harga dari $\mathrm{R}^{2}$. Adapun grafik isoterm Langmuir dan Freundlich secara bertutut-turut disajikan pada Gambar 5 dan 6.

Isoterm Langmuir menunjukan bahwa proses adsorpsi antara adsorben dan adsorbat terjadi secara kimia dan membentuk suatu lapisan tunggal (monolayer). Sedangkan isoterm Freundlich megindikasikan bahwa adsorpsi terjadi secara fisika dengan membentuk lebih dari satu lapisan (multilayer). Adapun hasil data isoterm Langmuir dan Freundlich disajikan pada Tabel 1. 


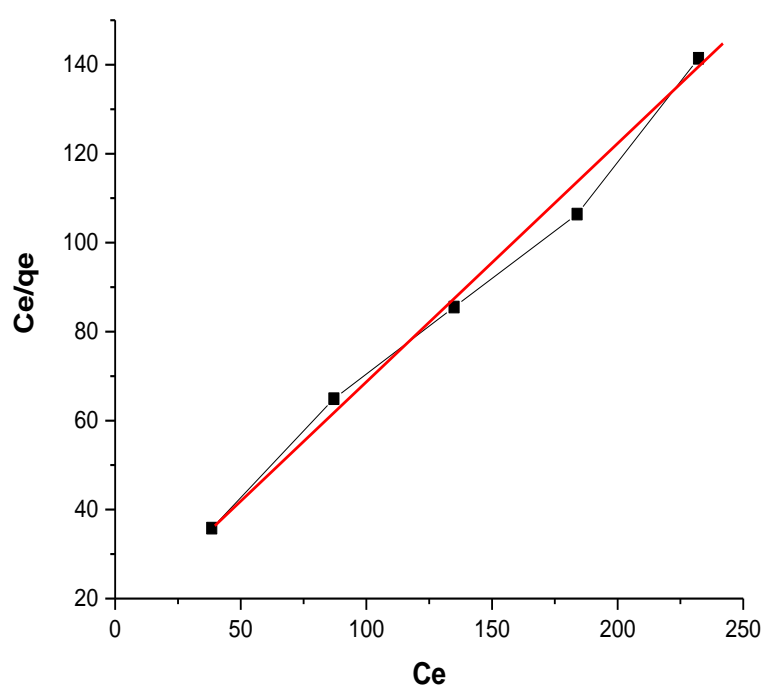

Gambar 5. Grafik Isoterm Adsorbsi Langmuir

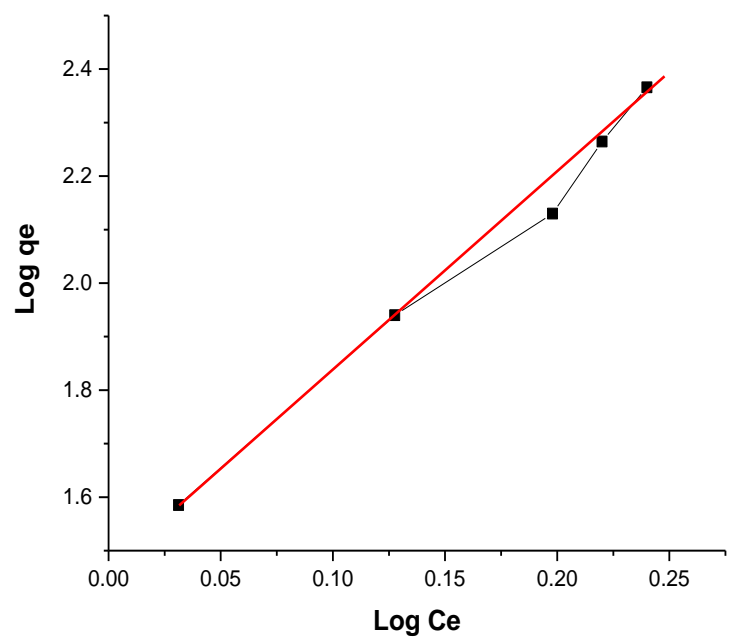

Gambar 6. Grafik isoterm adorpsi Freundlich

Tabel 1. Data isoterm Langmuir dan Freundlich

\begin{tabular}{lll} 
& Isoterm Adsorpsi & Adsorben Zeolit Alam Aktif \\
\hline Langmuir & & \\
& Qm & $1,99 \mathrm{mg} / \mathrm{g}$ \\
& $\mathbf{K}$ & $0,027 \mathrm{~L} / \mathrm{mg}$ \\
& E adsorpsi & $20,04 \mathrm{KJ} / \mathrm{mol}$ \\
& $\mathbf{R}^{\mathbf{2}}$ & 0,997 \\
\hline Freundlich & & \\
& $\mathbf{N}$ & 0,274 \\
& $\mathbf{K}$ & $29,25 \mathrm{~L} / \mathrm{mg}$ \\
& $\mathbf{R}^{\mathbf{2}}$ & 0,988 \\
\hline
\end{tabular}


Hasil data isoterm menunjukkan bahwa adsorpsi berlangsung secara dominan mengikuti sistem adsorpsi Langmuir. Hal ini diindikasikan dengan nilai $\mathrm{R}^{2}$ yang yang relatif besar dibandingkan hasil isoterm Freundlich, yakni sebesar 0,988. Hasil tersebut menunjukkan bahwa interaksi antara ZAA dengan zat warna Remazol Yellow FG terjadi secara kimia, yakni melalui sulfonat pada Remazol Yellow FG yang berinteraksi dengan situs aktif ZAA. Selain itu, adsorpsi ini juga mengikuti isoterm Freundlich yang mana interaksi terjadi secara fisika melalui gaya Van der Waals. ZAA memiliki muatan yang cenderung elektronegatif sehingga dapat berinteraksi membentuk ikatan lemah dengan ion-ion sulfonat pada zat warna Remazol Yellow FG. Gaya tarik menarik yang lemah tersebut menyebabkan adsorbat dapat bergerak dari satu bagian permukaan ke bagian permukaan lain dari adsorben sehingga dapat membentuk lebih dari satu lapisan.

\section{KESIMPULAN}

Berdasarkan penelitian yang telah dilakukan maka dapat disimpulkan bahwa:

1. Karakteristik zeolit alam aktif (ZAA) hasil dari modifikasi zeolit alam (ZA) termasuk ke dalam zeolit tipe mordenit. Adanya proses modifikasi tidak mengubah struktur utama dari zeolit melainkan hanya menurunkan pengotor-pengotornya.

2. $\mathrm{pH}$ optimum adsorpsi ZAA terhadap adsorpsi zat warna Remazol Yellow FG dicapai pada kondisi optimum $\mathrm{pH}$ sebesar 6 dan waktu kontak selama 120 menit.

3. Proses adsorpsi yang sesuai di sini adalah model isoterm adsorpsi Langmuir dengan $\mathrm{R}^{2}$ sebesar 0,998 dan energi sebesar 20,04 KJ/mol. Kapasitas adsorpsi model isoterm Langmuir adalah sebesar 1,99 mg/g.

\section{DAFTAR PUSTAKA}

Aydin, F., (2011) Removal of Reactive Textile Dyes (Remazol Brillant Blue R and Remazol Yellow) by SurfactantModified Natural Zeolite 30, 141-151. https://doi.org/10.1002/ep

Dehghani, M.H., Dehghan, A., Alidadi, H., (2017) Removal of methylene blue dye from aqueous solutions by a new chitosan / zeolite composite from shrimp waste: Kinetic and equilibrium study 34, 1699-1707. https://doi.org/10.1007/s11814-017-0077-2

Gao, H., Zhao, S., Cheng, X., Wang, X., \& Zheng, L. (2013) Removal of anionic azo dyes from aqueous solution using magnetic polymer multi-wall carbon nanotube nanocomposite as adsorbent. Chemical Engineering Journal, 223, 84-90.

Handayani, D.S., Kusumaningsih, T., Handayani, D.S., Kusumaningsih, T., Talip, L.F.A., Ramli, M.M., (2016) Adsorption of remazol yellow FG from aqueous solution on chitosan-linked P-T-Butylcalix [ 4 ] Arene Adsorption of remazol yellow FG from aqueous solution on. https://doi.org/10.1088/1757$899 \mathrm{X} / 107 / 1 / 012011$

Humelnicu, I., Alexandru, U., Cuza, I., Ignat, M., Academy, R., Viorica, D., Alexandru, U., Cuza, I., (2016) The Removal of Basic Blue 41 Textile Dye from Aqueous Solution by Adsorption onto Natural Zeolitic Tuff: Kinetics and Thermodynamics The removal of Basic Blue 41 textile dye from aqueous solution by adsorption onto natural zeolitic tuff: Kinetics and thermodynamics. https://doi.org/10.1016/j.psep.2016.11.016

Li, C., Zhong, H., Wang, S., Xue, J. and Zhang, Z., (2015) Removal of basic dye (methylene blue) from aqueous solution using zeolite synthesized from electrolytic manganese residue. Journal of Industrial and Engineering Chemistry, 23, pp. 344-352.

Liu, S., Ding, Y., Li, P., Diao, K., Tan, X., Lei, F., Zhan, Y., Li, Q., Huang, B and Huang, Z., (2014) Adsorption of the anionic dye Congo red from aqueous solution onto natural zeolites modified with $\mathrm{N}, \mathrm{N}$-dimethyl dehydroabietylamineoxide. Chemical Engineering Journal, 248, pp. 135-144.

Mockovčiaková, A., Matik, M., Orolínová, Z., Hudec, P., Kmecová, E., (2008) Structural characteristics of modified natural zeolite. J. Porous Mater. 15, 559-564. https://doi.org/10.1007/s10934-007-9133-3

Montalvo, S., Guerrero, L., Borja, R., Sánchez, E., Milán, Z., Cortés, I., Angeles de la la Rubia, M., (2012) Application of natural zeolites in anaerobic digestion processes: A review. Appl. Clay Sci. 58, 125-133. https://doi.org/10.1016/j.clay.2012.01.013

Ngah, W.S.W., Teong, L.C., Hanafiah, M.A.K.M., (2011) Adsorption of dyes and heavy metal ions by chitosan composites : A review. Carbohydr. Polym. 83, 1446-1456. https://doi.org/10.1016/j.carbpol.2010.11.004

Prasetyo, W.E., (2018) Sintesis Senyawa Diasilfloroglusinol melalui Reaksi C-Asilasi Friedel-Craft dalam Kondisi Bebas Pelarut menggunakan Katalis Zeolit Alam Aktif. Skripsi, Universitas Sebelas Maret, Surakarta. 
Saputra, M D Prameswari, V T D Kinanti, O D Mayasari, Y D Sutarni, K Apriany and W W Lestari, E., (2017) Preparation, Characterization and Methylene Blue Dye Adsorption Ability of Acid Activated-Natural Zeolite Preparation, Characterization and Methylene Blue Dye Adsorption Ability of Acid ActivatedNatural Zeolite.

Trisunaryanti, W., Syoufian, A., \& Purwono, S., (2013) Characterization and Modification of Indonesian Natural Zeolite for Hydrocracking of Waste Lubricant Oil into Liquid Fuel Fraction. Chemical Engineering Journal, 7, 175-180.

Wahyuningsih, S., Estiningsih, P., Anjani, V., Purnawan, C., Pramono, E., Sciences, N., Maret, U.S., Sciences, N., Maret, U.S., (2017) No Title 12, 126-132. https://doi.org/10.20884/1.jm.2017.12.2.321

Wang, S., Peng, Y., (2010) Natural zeolites as effective adsorbents in water and wastewater treatment 156, 11-24. https://doi.org/10.1016/j.cej.2009.10.029

Yan, K., Mun, J., Chee, C., Nan, M., Jin, B., Saint, C., Eong, P., Aryal, R., (2016) Evaluation of physicochemical methods in enhancing the adsorption performance of natural zeolite as low-cost adsorbent of methylene blue dye from wastewater. J. Clean. Prod. 1-13. https://doi.org/10.1016/j.jclepro.2016.01.056

Zhong, Q.Q., Yue, Q.Y., Li, Q., Gao, B.Y., Xu, X., (2014) Removal of Cu(II) and Cr(IV) from wastewater by an amphoteric sorbent based on cellulose-rich biomass. Carbohydr. Polym. 111. 788-796. 